\title{
Impact of Basel Accord on Banking System (Evidence from Islamic Banks of Pakistan)
}

\author{
Mr.Muhammad Mehtab Azeem ${ }^{1}$,Prof.Dr.Akin Marsap ${ }^{1} \&$ Assist.Prof.Dr.Cigdem Ozari ${ }^{1}$ \\ ${ }^{1}$ Department of Economics and administrative Science, Istanbul Aydin University, Pakistan. \\ Corresponding:Muhammad Mehtab Azeem, Istanbul Aydin University \& Francois Rabelais University, MBA, Pakistan.
}

Received: January 30, 2015

Accepted: February 26, 2015

Available online: March 17, 2015

doi:10.11114/afa.v1i2.724

URL: http://dx.doi.org/10.11114/afa.v1i2.724

\begin{abstract}
Banks and bank regulatory authorities are vital players for the stability of economy and financial system in potential way. Basel III and its related to capital's requirement obligations have been effective useful tool for the banking system. Since, this is tough job for the bankers to maintain the liquidity for hedging the future risk but it also been expensive for bankers to keep the extra capital and become more liquid since this discourage the provision of loans but promote the credit ratings. However, it has become necessary to investigate the impact of Basel III on Islamic banking system and analyze the trade off. The study analyzes empirically on the (Financial) anomalies in term of three factors (i) Financial size (ii) Spread and (iii) Provisions for non performing financing. The study also discusses the impact of Basel III on Islamic banking performance if applicable, in context of trade off and impact on country's economy. We can ask that Basel III framework is difficult to be consistent for conventional banks; we can also realize that either new regulation will be flexible for Islamic banks under Basel III while Islamic and Conventional banks are totally different. Further, we shall estimate if the Basel III is more or less important in Islamic banks of Pakistan than conventional banks. At the end, we shall see from theoretical framework either the impact of Basel III is important for Islamic banks if and only if Islamic banks adopt to follow Basel III regulations and analyzing the potential influence on conventional banks.
\end{abstract}

Keywords: Basel Accord III, Islamic banks, Behavioral Finance

\section{Literature Review}

There are numerous studies of Basel accord on commercial banks and implication on conventional banks along with impact of these banks on behavioral finance. Islamic banks seem to be unsurpassed in this research. Several studies on Basel accord has been done by Furlong (1992), Haubrich (1993), Bernake (1995), Peristiani (1996), Furfine (2000), Ferri (2001). They summarized that banks that are unable to maintain Basel accord regulations are tougher regulations for them but advantageous at least to safer their financial crisis and retaining capital adequacy ratio. They also investigated that result of credit crisis are due to supplying limited loans and keeping higher capital because of basel accord regulations but these studies are phenomenon. Further studies have been conducted by Bernanke \& Gertler (1995). They found that difficult requirements of capital produce barriers on bank's performance to acquire extra fund if they needed. Ismail (2003) concluded in context of Malaysian Islamic banks that banks can maintain capital requirement if only converting their financial volumes in shape of securities while adopting Basel accord II. He also concluded that by following this regulation, bankers can reduce riskier assets increase capital adequacy ratio by transferring their assets into 20 percent risk weighted category from larger risk weighted categories.

Similarity report has been done by Kim \& Moreno (1994) on Japanese commercial banks that financial regulatory institutions impose on Japanese banks to be careful on their capital requirements that resulted on turn off their lending position later on. Contradict of this opinion, each banks in Japan should have tendency to reduce lending if their capital adequacy ratio is lower ( Ito \& Sasaki, 1998). International regulatory requirements on banks slightly reduce loan expansion in Japan than domestic standardized requirements (Honda, 2002).

The superior studies of Japanese banks based on Basel accord is conducted by Montgomery (2005). He found that maintaining capital adequacy ratio on Japanese banks has shifted their financial portfolio away from the high weighted risk assets. Angelini (2011) investigated through theoretically that there could be significant cost of maintaining capital requirement and it increase bank's marginal cost of loans that resulted marginal cost of loans become higher than marginal cost of depositing fund. Higher cost of equity requirement to financing debt increase the cost of credit growth 
and slow down the stability of economy.

United States banks identified the impact of increasing equity to asset ratio and have found an increasing of spreads numerically upper bound six points that cause to increase capital to asset ratio by adopting Basel III (Kashyap, Stein \& Hanson, 2010). The higher increase in lending spread has been estimated by BIS (2010b) based on gap points of 12.2 \& 15.5 , by using thirty eight macro-economic models stabilize by central banks of developed countries.

The liquidity management centre established in February 2002, enable Islamic banking industry to manage an asset, mismatch of liquidity, create and improve asset quality, promote sharia credibility and create cooperative framework in achieving assets from government bodies, corporations and financial institutions. It enables to achieve higher return from investors and provide liquid investment opportunities for IFSIs.

The international Islamic Financial Market facilitate to create Islamic financial products and to auditing the liquidity requirement for Islamic banking industry. Its overall strengthen in achieving foreign direct investment and facilitate investment opportunities for foreign investors. It enhances the efficiency in regard to manage liquidity. The accounting and Auditing organization for Islamic banking industry also facilitate in the development of standards and regulations for Islamic banks and working with IMP, International accounting standards board \& Basel committee.

\section{Basel Accord III}

Financial crunch of 1970 \& 1980 imposed G-10 countries to take strict actions and find parameters by which banks can safe their risks. In response of it, Basel committee for banking regulations in (1988) introduced a minimum capital requirement in banking sector in order to secure the future risk for bankers known as Basel Capital Accord BIS (2010). The Basel I \& II implemented in response of these financial crisis, later on securing non performing loans in developing countries (Kandil, 2008).

Financial crunch again in 2007-08 urged banks for settlements to construct new regulations known as Basel III. The aim of implementing Basel III is to stabilize the economy and prevent from financial shocks strictly. This section aims on nature of Basel III impact on Islamic banks. Basel III is actually different from Basel I and II because it connects micro and macro advisory reforms and it address institutional level and system level risk together. Under Basel III, banks are forced to increase capital requirement Tier 1 to minimum 6 percent of risk weighted assets and this capital must be in form of equity. Further, banks are required to posses' capital conservation buffer of 2.5 percent in order to stand with future crunch. The aim of these requirements is in line with securing future losses. There will also be countercyclical buffer range from 0 to 2.5 percent of common equity. Financial Instruments with 10 years maturity according to Basel III will be executed and those 5 years maturity period according to Basel II Tier 2 will no longer exist in Basel III and phased out. Banks will be required to delete excessive investment in the capital instruments under the deductive approach.

On the other side, Islamic banks are limited in numbers. Basel III will be less impacting on Islamic banking system. For instance, Governor of National Bank of Malaysia addressed in 'Global Financial Magazine' that Malaysian Islamic banks already maintaining high liquidity coverage ratio and its relatively similar to Basel II framework. Thomas and Dalia (2011) has been examined the banks behavior in developed countries from 2001-2009 and found the result that larger banks would increase the lending rates by sixteen basis points in order to reach the equity to asset ratio by 1.3 percent points and seven percent equity to new risk weighted asset ratio and this impact the cost of equity nearly 16 basis points other than alternative bank resources under Basel III. Rajhi, (2012) empirically assessed the insolvency risk between Islamic and conventional banks using stability indicator (Z-Score as an exogenous variable) in North America, Middle east and Southeast Asia and found that Islamic banks are more stronger than conventional banks. Cihak and Hesses in (2010) found that small Islamic banks that concentrate only on low risk investments are stable and large Islamic banks that focus on profit sharing investments are less stable than small Islamic banks. Kara in (2011) investigated that Islamic banks are more capitalize due to Sharia compliance and holding large capital under Tier 1.Actually,Islamic bank's source of financing consist on 'Own capital', 'Demand deposit' \& 'Profit sharing investment' so deposited insurance is not necessary and reduce the cost of financing (Boumediene,2011). Mohammad Bitar, (2011) assessed the impact of Basel III on Islamic and Conventional banks using panel date of 11487 conventional banks and 146 Islamic banks in 76 countries during the period of 2005-2011 and found that impact of liquidity, leverage and capital is not significant correlated between Islamic and conventional banks and their risks also varies.

\section{Islamic Banks and Basel accord Implication in Pakistan}

The Basel committee decided to increase the capital ratio during period 2013-2018 with minimum level of common equity will be arisen from 2 percent to 4.5 percent and minimum capital adequacy ratio will be exceeded from 9 to 12 percent. Islamic banks in Pakistan mix with religious forces and playing an active role in growth of country's economy. Currently there are 14 conventional banks (Report of Islamic Banks Bulletin, 2013) that hold license of Islamic sharia to work accordingly. Conventional banks also in response to operate according to Islamic banks if and only if they hold 
license of it. Islamic Banks holding total assets amount 1014 billion dollar and market shares 8.8 percent as reported by State bank of Pakistan on December 2013.There are more than 1225 branches (State Bank of Pakistan Annual Report,2013)in Pakistan and it is increasing consecutively. State bank of Pakistan plays an important role in line with regulation of Islamic Sharia compliance is parallel to international standardized regulations.

Capital framework of Islamic banks is not similar as conventional banks. In Islamic banks, Capital consists of Tier 1 Capital and some extent of Tier 2. Best capitalized system on global parameter belongs with Islamic banks Capital compared to advanced countries.Tier1 and capital requirement policies currently amply at eight percent to twelve percent which is already higher than the expected ratio of 2019, set by Basel III as capital structure is more derivatives and low level selling is forbidden. Islamic banks can not follow Basel III until Islamic Financial services should modify in Basel III according to their specifications and permit to Islamic banks to follow new International standards.

State bank of Pakistan has imposed of practicing Basel II, using standardized approach for both Islamic and conventional banks in order to avoid risk from 1st Jan, 2008 and Internal rating based (IRB) approach from Jan, 2010. State Bank has derived the parallel program to execute1 and half year standardized approach and 2 years IRB program from 2006-2008 respectively.

This paper shed lights on examining Basel I and II empirically on financial practices (Financial size, Spread \& Provision for non performing financing and interpretation the impact of Basel III on Islamic banking system. The remainder section ' 4 ' and ' 5 ' explain the methodology and conclusions and recommendations.

\section{Basel III Model}

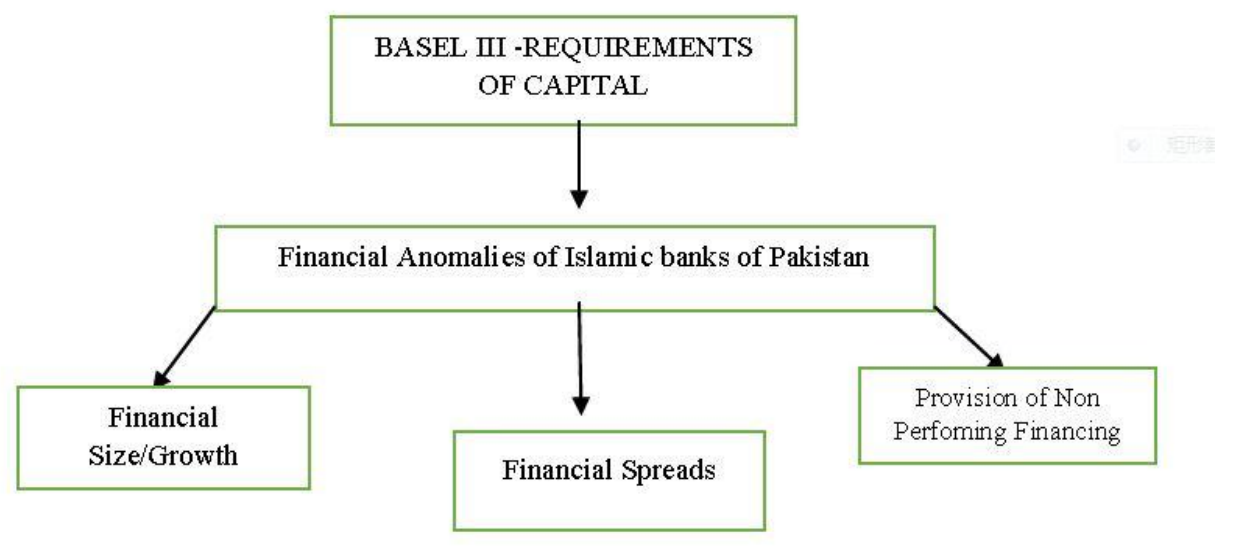

\section{Methodology}

Several past studies have been conducted in line with adoption of Capital standards of Basel I, II and III with respect to emerging economic countries and advanced countries in the context of conventional banks (Bizer, 1993; Haubrich \& Wachtl, 1993; Baer \& McElravry, 1994; Berger \& Udell, 1994; Peek \& Rosengran, 1995). In order to investigate the impact of Basel accord on financial crisis attributed with forceful actions from the regulatory authorities, the study has been constructed through annual time series and cross sectional panel of Islamic banks of Pakistan. The study investigate three parameters on bank's financial behavior (Financial spreads, Provision of nonperforming loans and financial size in terms of growth).The investigation of empirical study based on Basel I and II is also counterpart of this paper. Data consist of 9 Islamic banks within a period of 2010 to 2013.Model explore the proceeding nature of analysis

$$
\text { (i). }
$$$$
\mathrm{FS}_{\mathrm{it}}=\alpha_{+} \beta_{1} \mathrm{CR}_{\mathrm{it}+} \varepsilon \text { it }
$$

$$
\text { Spead }_{i t}=\alpha_{+} \beta_{1} \mathrm{CR}_{\mathrm{it}+} \varepsilon \text { it }
$$

(iii)

$$
\text { Provision }_{\mathrm{it}}=\alpha_{+} \beta_{1} \mathrm{CR}_{\mathrm{it}+} \varepsilon \text { it }
$$

Dependent Variables= Financial Anomalies (Financial Size (FS), Spreads \& Provisions)

Independent Variable $=$ Capital to asset ratio according to Basel accord. 
Sample Period: 2010-2013

Dependent Variable: Total Financing to Asset ratio

\begin{tabular}{lllll}
\hline Variables & Coefficient & Standard Error & T-Statistics & Prob. \\
\hline C & 0.1714 & 0.0581 & 3.0050 & 0.0051 \\
$\begin{array}{l}\text { Capital to asset } \\
\text { Ratio }\end{array}$ & 2.2773 & 0.4810 & 4.7340 & 0.0000 \\
$\begin{array}{l}\text { Effects Specification } \\
\text { Durbin-Watson Stat }\end{array}$ & 1.8000 & & & \\
Log Likelihood & 27.9067 & & F-Statistics & 3.4490 \\
R-Squared & 0.5190 & Prob (F-Statistics) & 0.0038 \\
Adjusted R-Squared & 0.4018 & Mean Dep Variable & 0.4190 \\
S.E of Regression & 0.1550 & S.D.Dep Variable & 0.1810 \\
Sum squared resid & 0.6980 & Akaike info & -0.8200 \\
\hline
\end{tabular}

Method: Panel Least square

Cross sectional included: 9

Total panel unbalanced observations: 44

Table 2.Islamic Banking Industry of Pakistan Progress (Rupees in Billions)

Average total assets in 2010 were Rs.477 billion which increased to Rs1014 billion in 2013.Net Investments also grew from Rs.338 to Rs.709 billion from the period 2010 to 2013.

\begin{tabular}{|lllll|}
\hline Total Assets & 2010 & 2011 & 2012 & 2013 \\
\hline Deposits & 390 & 641 & 837 & 1014 \\
\hline $\begin{array}{l}\text { Net Financing } \\
\text { \& Investment }\end{array}$ & 338 & 521 & 706 & 868 \\
\hline $\begin{array}{l}\text { Provision to } \\
\text { Non } \\
\text { performing } \\
\text { financings }\end{array}$ & $70.6 \%$ & 475 & 626 & 709 \\
\hline $\begin{array}{l}\text { Return on } \\
\text { Equity }\end{array}$ & $9.8 \%$ & $67 \%$ & $71.8 \%$ & $78.4 \%$ \\
\hline
\end{tabular}

Source: Islamic Banking Bulletin December, 2013

Table. 01 assessed the empirical model of (i).There is significant positive relationship between total investment to asset ratio and capital to asset ratio from the period 2010-2013 in response to Islamic banks Pakistan. The result is opposite of the empirical studies conducted by Chiuri, Ferri \& Majnoni in (2001) in context of conventional banks for developing countries. According to them, maintaining capital requirement under Basel III may lead slowly down lending actions that later on can cause credit crisis. This lending activities can become more worsen in case if there are not lending institutions other than banks and it impact on country's economy at large. Basel III imposes to increase capital adequacy ratio that resulted credit crunch under Basel accord. But Islamic banks of Pakistan contrary to the opinion of Chiuri, Ferri and Majnoni (2001) are still growing their financial volumes since implemented Basel accord and their capital adequacy ratio is stabilize .Table.02 shows that Investments of Islamic banks grew from Rs.338 billion to Rs. 709 billion from 2010-2013 that concluded that Islamic banks are investing their assets in less riskier categories and stabilizing their capital adequacy ratio. This study is relevant to study of Ismail (2003) who says that Islamic banks should invest their fund into government securities (e.g., Government securities, bonds that have less risky weighted assets and increases capital to asset ratio easily).

Table 3.Spread to Asset ratio with Capital to Assets ratio for Islamic banks of Pakistan

Dependent Variable: Spread

Sample Period: 2010-2013 


\begin{tabular}{lllll}
\hline Variables & Coefficient & Standard Error & T-Statistics & Prob. \\
\hline C & 0.00930 & 0.00820 & 1.1380 & 0.2770 \\
$\begin{array}{l}\text { Capital to asset } \\
\text { Ratio }\end{array}$ & 0.3330 & 0.0710 & 4.6057 & 0.0001 \\
$\begin{array}{l}\text { Effects Specification (Cross sectional fixed, dummy variables) } \\
\text { Durbin-Watson }\end{array}$ & 2.1651 & & \\
Stat & 114.2600 & F-Statistics & 6.4555 \\
$\begin{array}{l}\text { Log Likelihood } \\
\text { R-Squared }\end{array}$ & 0.6369 & Prob (F-Statistics) & 0.0002 \\
$\begin{array}{l}\text { Adjusted R- } \\
\text { Squared }\end{array}$ & 0.5674 & $\begin{array}{l}\text { Mean Dep } \\
\text { Variable }\end{array}$ & 0.0440 \\
S.E of Regression & 0.0224 & S.D.Dep Variable & 0.0333 \\
& & Akaike info & -4.6710 \\
Sum squared resid & 0.0191 & Criterion & \\
\hline
\end{tabular}

Method: Panel Least squares

Cross sectional included: 9

Total panel unbalanced observations: 44

Table. 03 estimated the empirical model (ii).There is significant correlation between spread ratio and capital to asset ratio for Islamic banks in Pakistan. The study is relevant with kashyap etc, (2010) \&Angelini (2011) for conventional banks in emerging economic countries. They found that for the increase of U.S banking spreads by upper bound of 6 basis increase capital to asset ratio under Basel III.

Table 4.Results of the Provisions for financing Asset ratio with Capital to Assets ratio for Islamic banks of Pakistan Sample Period: 2010-2013

Dependent Variable: Provisions for non performing loans

\begin{tabular}{|c|c|c|c|c|}
\hline Variables & Coefficient & Standard Error & T-Statistics & Prob. \\
\hline $\mathrm{C}$ & -0.0091 & 0.0040 & -2.1080 & 0.0501 \\
\hline $\begin{array}{l}\text { Capital to asset } \\
\text { Ratio }\end{array}$ & 0.1740 & 0.04050 & 4.1974 & 0.0004 \\
\hline Effects Specification & \multicolumn{3}{|c|}{ (Cross sectional fixed, dummy variables) } & \\
\hline Durbin-Watson Stat & 2.3300 & & F-Statistics & 6.1050 \\
\hline Log Likelihood & 140.0150 & & Prob (F-Statistics) & 0.0009 \\
\hline R-Squared & 0.6260 & & Mean Dep Variable & 0.0090 \\
\hline Adjusted R-Squared & 0.5201 & & S.D.Dep Variable & 0.0201 \\
\hline S.E of Regression & 0.0118 & & $\begin{array}{l}\text { Akaike info } \\
\text { Criterion }\end{array}$ & -5.8222 \\
\hline Sum squared resid & 0.0050 & & Schwarz Criterion & -5.4220 \\
\hline
\end{tabular}

Method: Panel Least squares

Cross sectional included: 9

Total panel unbalanced observations: 44

Table No.04 shows the result of model (iii). There is significant positive correlation between provisions and capital to asset ratio during the period 2010-2013.The result is similar to study of Ismail (2003) for Malaysian Islamic Banks. If banks invest on riskier projects then maintaining higher capital adequacy ratio is necessary. Increase of provision for non performing loans with regard to require higher capital ratio in Islamic banks of Pakistan resulted that banks board of directors are engage in more riskier projects and perceive higher risks also calculate more provisions for capital reserves.

\section{Conclusions and Recommendations}

Islamic banks in Pakistan promote their investment approach intentionally by maintaining capital adequacy ratio under Basel Accord II\&II. This approach arise the motivation for Islamic banks to diversify their investment into government securities and increase capital ratio through less weighted risks activities and stabilize their financial portfolio. In 
addition, Islamic banks in Pakistan increase their spreads along with increase capital ratio under Basel I and II. As under Basel III ,the capital requirement become more curious, it is estimated that dependent variables (Financial size, spreads \& Provision for non performing loans ) will be adversely affect by an increasing capital adequacy ratio. Future research will be investigating the impact of Basel III along with capital simulation approach. Policy makers should realize the adverse and positive impact by implementing Basel III on banking sectors especially in term of (Investments, Financial size, Speads, Provisions and tradeoff). Basel III will have impact on business strategies and plans especially for conventional banks and need to introduce new modification such as computation of risks, new ratios on solvency, Asset value relationship, new capital buffers and new terminologies in term of leverage and liquidity. Despite of those facts, Basel III has failed to create distinction between Islamic and Conventional banks and collaboration is curios matter between Basel committee and Islamic Financial service board. The majority of Islamic banks already maintaining sufficient capital requirement instead of Basel accord requirements.

We can justify through example that was pasted on 'Investor guide magazine' in 2011, In Qatar the average Tier 1 ratio is approx. 22.7 percent for 18 Islamic banks while Morgan Stanley Research department did survey under Basel III in three banks of Qatar and easily found that Basel III has limited impact on risks, own capital and ratios. The reason is that, lot of conventional banks will undergo a difficult time to adopt new Basel III regulatory requirements. Comparison of that, Conventional banks will be suffered higher risk in term of own funds and return on investment and with expected financial crisis these banks should rethink to reform the Basel III that should be more effective and efficient like in France, where local lending institutes is effected by commercial banks because maturities time was too high.

Another result, from the theoretical point of view, Islamic banks are less effective than conventional banks and conventional banks are more effective in term of leverage ratio, liquidity ratio, liquidity coverage ratio while Islamic financial institutions hold global appeal in its provision of Sharia complaints.

\section{References}

Angelini, P., L., Clerc, V., Curdia, L., Gambacorta, A., Gerali, A., Locarno, R., Motto, W., Roeger, S., Van den H., \&Vlcek,J. (2011).Basel III: Long-Term Impact on Economic Performance and Fluctuations, Federal Reserve Bank of New York Staff Report, 485.

Adel, H. (2012), The impact of Basel III on Islamic banks: A theoretical study and comparison with conventional banks, Paper presented first time at the research chair ethics and financial norms of University Paris 1 La Sorbonne and the King Abdul University.

Baer, H. L., \& John, M. (1993).Risk-Based Capital and Bank Growth, Working Paper, Federal Reserve Bank of Chicago.

Ben, N. S., \& Magda, K.(2007). Basel Accord and Lending Behavior: Evidence from Mena Region. Available at http://papers.ssrn.com/sol3/papers.cfm?abstract_id=1018747

Berger, A. N., \& Gregory, F. U. (1994).Did Risk-Based Capital Allocate Bank Creditand Cause a 'Credit Crunch' in the United States? Journal of Money, Credit, and Banking, 26, 585-628.

Bernanke, B. S., \&Gertler,M. (1995).Inside the Black Box: The Credit Channel ofMonetary Policy Transmission, Journal of Economic Perspective, 9, 27-48.http://dx.doi.org/10.1257/jep.9.4.27

Bernanke, B. S.,\&Lown,C. (1991).The Credit Crunch, Brookings Papers on EconomicActivity , 2, 205-39.http://dx.doi.org/10.2307/2534592

Bizer, D. S. (1993). Regulatory Discretion and the Credit Crunch, Working Paper, U.S.Securities and Exchange Commission, Washington D.C., April.

Brinkmann, E.,\& Paul, H. (1995). Risk-based Capital Standards and the CreditCrunch, Journal of Money, Credit, and Banking, 27, 848-863.http://dx.doi.org/10.2307/2077755

Boumediene, A. (2011) Basel III: Relevance for Islamic Banks, Pantheon-Sorbonne University. http://m.risk.net/digital_assets/4562/v7n3a4.pdf

Cantor, R.,\& John, W.(1993). Perspective on the Credit Slowdown, Federal Reserve Bank of New York, Quarterly Review 18 (Spring 1993), 3-36.

Chiuri, M. C., Giovanni, F.,\& Giovanni, M. (2002). The Macroeconomic Impact of Bank Capital Requirements in Emerging Economies: Past Evidence to Assess the Future, Journal of Banking and Finance, 26, 881-904.http://dx.doi.org/10.1016/S0378-4266 (01)00267-9

Čihák, M., \& Hesse, H.(2008); Islamic Banks and Financial Stability: An Empirical Analysis , International Monetary Fund Working Paper, WP/08/16.Available at http://www.imf.org/external/pubs/ft/wp/2008/wp0816.pdf 
Errico, L., \& Mitra, F.(1998). Islamic Banking-Issues in Prudential Regulations and Supervision. International Monetary Fund.

Furfine, C.(2000). Evidence on the Response of US Banks to Changes in Capital Requirements, Bank of International Settlements Working Paper, 88.

Furlong, F. T. (1992). Capital Regulation and Bank Lending, Federal Reserve Bank of San Francisco Economic Review , 3, 23-313.

Hancock, D., Andrew, J. L., \& James, A. W. (1995). Bank Capital Shocks: Dynamic Effects on Securities, Loans, and Capital, Journal of Banking and Finance, 19(3-4), 661-77.http://dx.doi.org/10.1016/0378-4266(94)00147-U

Hancock, D., \& James, A. W. (1993). Bank Capital and Portfolio Composition, Federal Reserve Bank of Chicago, Conference on Bank Structure and Competition.

Haubrich, J. G.,\& Paul, W.(1993). Capital Requirements and Shifts in Commercial Bank Portfolios, Federal Reserve Bank of Cleveland Economic Review , 29,2-15.

Honda, Y. (2002). The Effects of the Basel Accord on Bank Credit: The Case of Japan, Applied Economics, 34, 1233-39.http://dx.doi.org/10.1080/00036840110094455

Ismail, A. G., \& Shahida, S. (2009). Do Risk-Based Capital Requirements Allocate Financing and Cause a Bigger Loan Loss Provision for Islamic Banks?

Jackson, P., Craig F., Hans G., Diana, H., David, J., William, P., Lawrence, R.,\& Masao, Y.(1999). Capital Requirements and Bank Behavior: The Impact of the Basel Accord, Basel Committee on Banking Supervision, Working Paper, 1 .

Khaldi, K., \& Hamdouni A.(2011). Islamic financial Intermediation: Equity, Efficiency and Risk, International Research Journal of finance and Economics, 65.

http://connection.ebscohost.com/c/articles/76481311/islamic-financial-intermediation-equity-efficiency-risk

Kashyap, A., J.,Stein, C. \& Hanson,S. (2010). An Analysis of the Impact of Substantially Heightened in Capital Requirements on Large Financial Institutions, Working Paper (Chicago: University of Chicago). http://chifl.shufe.edu.cn/upload/htmleditor/File/120919100455.pdf

Kim, S. R.,\&Moreno,R. (1994). Stock Prices and Bank Lending Behavior in Japan, Federal Reserve Bank of San Francisco Economic Review, 1, 31-42.

Malik, N. (2000) Regulatory framework needed if Islamic banking to advance further.www.IslamiQ.com. Dec. 14

Modigliani, F.,\&Miller,M. H. (1958). The Cost of Capital, Corporation Finance and the Theory of Investment, American Economic Review, 48, 261-297.

Mohammed, O. (2000). Capital adequacy norms for Islamic financial institutions. Research Paper. http://islamicfinance. net/research/paper2.html.

Mohammad Bitar. (2011).Basel 111 requirement and stability of Islamic and Conventional Banks.Université Pierre Mendès France Grenoble II- CNRS.

Muhammad, K.,\& Mervyn,K.L. (2007). Handbook of Islamic Banking, Library of congress control,file:///C:/Users/ACER/Downloads/Hassan-LewisHandbook\%20of\%20Islamic\%20Bank.pdf

Montgomery, H. (2001). The Effect of the Basel Accord on Bank Portfolios in Japan, a paper presented at NBER Japan Group Meeting.

Peek, J.,\& Eric, R. (1995a), The Capital Crunch: Neither a Borrower nor a Lender Be, Journal of Money, Credit, and Banking, 27, 625-638.http://dx.doi.org/10.2307/2077739

Rajhi, W.(2012), Islamic Banks and Financial Stability: A Comparative empirical Analysis between MENA and Southeast Asian Countries, University of South Toulon-Var.

Slovik, P.,\&Cournede,B. (2011), Macroeconomic Impact of Basel III, OECD Economics Department Working Papers, 844, (Paris: Organization for Economic Cooperation and Development Publishing).

Thoma, F.C.,\&Hakura,S.(2011).Bank behavior in response to Basel III'.A cross country analysis.IMF working Paper.

Wagster, J. (1999). The Basel Accord of 1988 and the International Credit Crunch of1989-1992, Journal of Financial Services Research, 15, 123-143.http://dx.doi.org/10.1023/A:1008023803152

Woo, D. (1999). In Search of a 'Capital Crunch': Factors behind the Credit Slowdown in Japan, IMF Working Paper No. WP/99/3. http://www.imf.org/external/pubs/ft/wp/1999/wp9903.pdf 


\section{Appendix}

Table 5. List of Islamic banks as of December, 2013

\begin{tabular}{clc}
\hline S.No. & Name Islamic Banks & No. of Branches \\
\hline 1. & Meezan Bank Limited & 349 \\
2. & AlBaraka Bank (Pakistan) Limited & 108 \\
3. & Bank Islami Pakistan Limited & 112 \\
4. & Dubai Islamic Bank Pakistan Limited & 124 \\
5. & Burj Bank Limited & 74 \\
Islamic Branches of Conventional Banks & \\
1 & Askari Bank Limited & 39 \\
2 & Bank Alfalah Limited & 139 \\
3 & Habib Bank Limited & 38 \\
4 & MCB Bank Limited & 27 \\
5 & The Bank of Khyber & 44 \\
6 & Bank Alhabib Limited & 17 \\
7 & Faysal Bank Limited & 53 \\
8 & Habib Metropolitan Bank Limited & 6 \\
9 & National Bank of Pakistan & 20 \\
10 & Silk Bank Limited & 10 \\
11 & Soneri Bank Limited & 9 \\
12 & Standard Chartered bank & 10 \\
13 & The bank of Punjab & 7 \\
14 & United bank Limited & 22 \\
\hline
\end{tabular}

Table 6. Classification of Capital according to Basel I, II \& III

\begin{tabular}{|c|c|c|c|}
\hline \multicolumn{2}{|c|}{ Bll (current version) } & \multicolumn{2}{|c|}{ Proposed new standard } \\
\hline \multirow[t]{5}{*}{ Tier 1} & $\begin{array}{l}\text { Common Stock and other forms of } \\
\text { Tier } 1 \text { (including perpetuals) }\end{array}$ & Tier 1 & $\begin{array}{l}\text { Common Equity (common stock } \\
\text { plus retained earnings and } \mathrm{OCl} \text { ) }\end{array}$ \\
\hline & $\begin{array}{l}\text { Disclosed reserves } \\
\text { (including from minority interests) }\end{array}$ & & Additional going concern capital \\
\hline & $\begin{array}{l}15 \% \text { innovative instruments } \\
\text { (Annex } 1 \text { to BII) }\end{array}$ & & n.a. \\
\hline & $\begin{array}{l}\text { Deduct goodwill and equity from } \\
\text { securitizations }\end{array}$ & & $\begin{array}{l}\text { Deduct goodwill and many other } \\
\text { items } 1: 1 \text { from common equity }\end{array}$ \\
\hline & $\begin{array}{l}\text { Deduct } 50 \% \text { of investments in other } \\
\text { financial institutions }\end{array}$ & & Transformed into 1:1 adjustment \\
\hline \multirow{4}{*}{$\begin{array}{l}\text { Tier } 2 \\
\max 100 \% \text { of } \\
\text { Tier } 1\end{array}$} & $\begin{array}{l}\text { Undisclosed reserves and asset } \\
\text { revaluation }\end{array}$ & Tier 2 & $\begin{array}{l}\text { Only one form of Tier } 2 \text { capital } \\
\text { remains }\end{array}$ \\
\hline & General loan-loss reserves & & $\begin{array}{l}\text { Unrealized gains will be reviewed } \\
\text { by BCBS until y/e } 2010\end{array}$ \\
\hline & Hybrid capital instruments & & n.a. \\
\hline & Subordinated debt ( $\max 50 \%$ of Tier 1 ) & & n.a. \\
\hline Tier 3 & $\begin{array}{l}\text { For market risk coverage } \\
\text { (limitations apply) }\end{array}$ & Tier 3 & n.a. \\
\hline
\end{tabular}

Source:Deloitte 
Fig.01

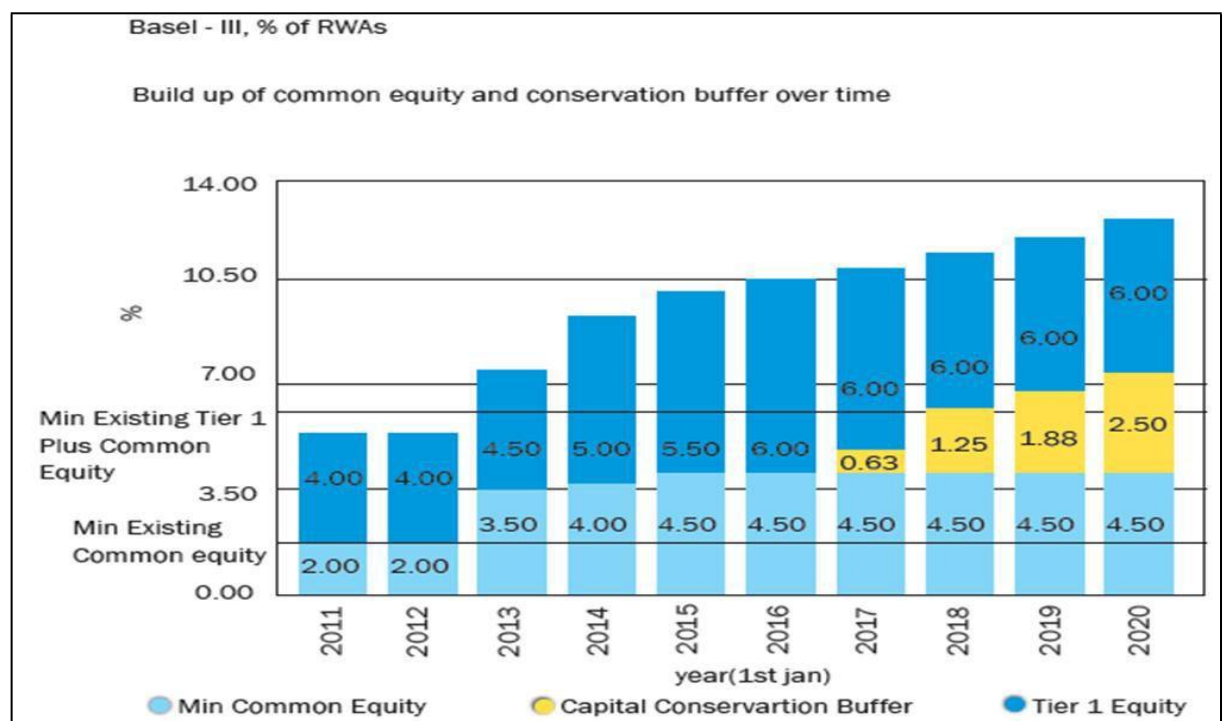

Figure1. Basel III new ratios

Source: http://www.basel-ii-risk.com/new-basel-iii-common-equity-by-year/

\section{(cc) $\mathrm{Br}$}

This work is licensed under a Creative Commons Attribution 3.0 License. 